\title{
Effect of Biopreservatives on storage life of papaya (Carica papaya L.)
}

\author{
Fatema H. Brishti $^{a^{*}}$, Jawadul Misir ${ }^{\mathrm{a}}$, ANd Ayesha SARker ${ }^{\mathrm{a}}$ \\ ${ }^{a}$ Department of Food Engineering and Tea Technology. Shahjalal University of Science and Technology, \\ Sylhet, 3114, Bangladesh \\ ${ }^{*}$ Corresponding author \\ brishti_hossain@yahoo.com \\ TEL: +821-0167-7202010
}

Received: 31 August 2012; Published online: 18 April 2013

\begin{abstract}
In this experiment the effect on post-harvest preservation of papaya (Carica papaya L.) fruit coated with either Aloe gel (AG; 100\%) or papaya leaf extract with Aloe gel (PLEAG; 1:1) was studied. To evaluate the role of coating on ripening behavior and quality of papaya the uncoated and coated fruits were stored and ripened at room temperature $\left(25^{\circ} \mathrm{C}-29{ }^{\circ} \mathrm{C}\right)$ and $82-84 \%$ relative humidity. Physicochemical properties were analyzed at 4 day intervals during the storage period. The incidence of disease attack was also visually observed. The overall results showed the superiority of AG and PLEAG coating in lengthening the shelf-life of papaya fruit compared to controls which showed significant decay from $6^{\text {th }}$ day onward and complete decay within 12 days of storage. The AG and PLEAG coated fruits maintained their shelf life for 12 days and decayed at $16^{t h}$ day. The coated fruits also maintained their color, flavor and firmness up to 12 days of storage. An increase in ascorbic acid content (120.2 $\mathrm{mg} / 100 \mathrm{~g}$ ) was also found in coated fruits in contrast to the control (59 mg/100 g). Only $27 \%$ disease incidence was observed in AG and $13 \%$ in PLEAG coated fruits as compared to control (100\%) during the storage period. The results of this study show that both AG and PLEAG coatings have excellent potential to be used on fresh produce to maintain quality and extend shelf-life.
\end{abstract}

Keywords: Aloe vera gel; papaya fruit; post-harvest; disease incidence; edible coating

\section{Introduction}

Papaya (Carica papaya L.) is a popular and economically important fruit of tropical and subtropical countries. Papaya ranks first among 13 to 17 fresh fruits for vitamin $\mathrm{C}$ content per 100 grams edible tissue (Gebhardt \& Thomas, 2002). As a human food, they are of excellent flavor and sweetness, and their nutritional value is high. One serving of papaya will meet about $20 \%$ of an adult's daily folate needs, and provides about $75 \%$ of an adult's daily vitamin $\mathrm{C}$ needs. Papaya fruits are rich in enzymes called papain and chymopapain used for meat tenderizing and chewing gum (Oloyede, 2005). Marketing of fresh papaya is a great problem because of its short post-harvest life, which leads to high post-harvest losses (Jayathunge, Prasad, Fernando, \& Palipane, 2011). Papaya fruits soften rapidly at room temperature after harvest and a 2 to 3 day shelf life is to be expected (Archbold, Koslanund, \& Pomper, 2003). If the fruits are not quite ripe, they may be refrigerated for about two weeks. There are few studies on the efficacy of edible coatings to reduce the perishability of papayas. Films and edible coatings are defined as "a thin application of material that forms a protective barrier around 
an edible commodity and can be consumed along with the coated product" (Guilbert, Gontard, \& Gorris, 1996). Edible coatings are used to create a modified atmosphere and to reduce weight loss during transport and storage (Baldwin, 1994). In fact, the barrier characteristics to gas exchange for films and coatings are the subjects of much recent interest (Tripathi \& Dubey, 2004).

Aloe vera is a well-known plant for its marvelous medicinal properties. It is a tropical and subtropical plant. There are some reports on the antifungal activity of Aloe vera gel against several fungi including Colletotrichum sp. (Nidiry, Ganeshan, \& Lokesha, 2011). Recently, interest has increased in using Aloe vera gel-based edible coating material for fruits and vegetables driven by its antifungal activity. Researchers from Spain have developed a gel based on Aloe vera that prolongs the conservation of fresh fruits (Valverde et al., 2005). This gel is tasteless, colorless and odorless. This natural product is a safe and environmentally friendly alternative to synthetic preservatives such as sulfur dioxide. According to the researchers, this gel operates through a combination of mechanics (Serrano et al., 2006), forming a protective layer against the oxygen and moisture of the air and inhibiting the action of micro-organisms that cause food borne illnesses through its various antibacterial and antifungal compounds. Aloe vera gel-based edible coatings have been shown to prevent loss of moisture and firmness, control respiratory rate and maturation development, delay oxidative browning and reduce microorganism proliferation in fruits such as table grapes (Castillo et al., 2010), sweet cherries (Martinez-Romero et al., 2006) and nectarines (Ahmed, Singh, \& Khan, 2009).

Furthermore, papaya leaf contains bioactive compounds which have antifungal (Bautista-Baños, Barrera-Necha, Bravo-Luna, \& BermúdezTorres, 2002) activity against Colletotrichum sp. Thus, the extracts of papaya leaf can be incorporated into Aloe vera gel to enhance the effectiveness of the anti-fungal activity of Aloe gel matrix.

In view of Aloe vera's favorable effect on fruits (sweet cherries, table grapes, granny smith and red chief apple) and increasing demands for eco-friendly, bio-based preservatives for post-harvest conservation of fresh produce, this investigation was conducted. The goal of this work was to analyze the efficacy of Aloe gel and papaya leaf extract incorporated Aloe gel-based coatings on storage life, disease incidence and quality attributes of papaya such as weight loss, total soluble solids (TSS), titrable acidity, $\mathrm{pH}$, ascorbic acid content, firmness and color changes.

\section{Materials and Methods}

\section{$2.1 \quad$ Plant materials}

Papayas (Carica papaya L.) were harvested at the preclimacteric stage ("nearly ripe"), with green color, though physiological maturation (local variety), from the Bibidoil village at lal-

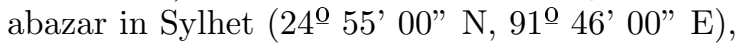
Bangladesh. Visually blemished, diseased, damaged papayas were discarded to minimize biological variability.

\section{Biopreservatives}

Aloe vera leaves were collected from Natore district ( $24.4139^{\mathrm{O}} \mathrm{N}, 88.9300^{\circ} \mathrm{E}$ ), Bangladesh. Papaya leaves were obtained from a papaya orchad in Shubid bazaar and Tilagor of Sylhet division, Bangladesh.

\subsection{Methods}

Fresh Aloe vera leaves were taken. Aloe gel matrix lies underneath the green outer leaf rind. The gel matrix was separated from the outer cortex of leaves and this colorless hydroparenchyma was ground in a blender. The resulting mixture was then filtered to remove the fibers. The liquid obtained was the fresh Aloe gel (AG; 100\%). The Aloe gel was pasteurized at $70{ }^{\circ} \mathrm{C}$ for 45 min (Maughan, 1984). It was then cooled immediately at ambient temperature. To facilitate coating the gel was thickened using $1 \%$ gelling agent (High Methoxyl pectin, Anhui Yuning BioTechnology Co., Ltd, Wanguo).

To prepare papaya leaf extract along with Aloe gel (PLEAG, 1:1), $500 \mathrm{~g}$ papaya leaves were first washed with running water. After that the leaf 
surface was sterilized using $0.1 \%$ mercuric chloride for $10 \mathrm{~min}$ (El-Kadder \& Hammad, 2012) and again washed thoroughly with sterile distilled water. Papaya leaves were then crushed along with Aloe gel. Filtration was carried out to remove fiber.

\subsection{Treatments}

For each treatment 25 fruits were used. Fruits were first washed and dried at room temperature. Then $100 \%$ AG and PLEAG (1:1) were brushed on papaya fruits and allowed to dry for about $1 \mathrm{hr}$ at room temperature. All the fruits were air-dried to form a thin film on the fruit surface and stored in bamboo baskets. Uncoated fruits were used as control and stored under the same storage conditions used for AG and PLEAG coated fruits. Physico-chemical properties were measured initially and at 4-day intervals. The experiments were replicated five times.

\subsection{Total Soluble Solids (TSS) and $\mathrm{pH}$}

TSS of papaya juice was determined using a Hand Held Refractometer (REF102/112, China) and the data were recorded as ${ }^{\circ}$ Brix. $\mathrm{pH}$ was measured using a digital $\mathrm{pH}$ meter (Jenco $6173 / \mathrm{R}$, China) and the data recorded.

\subsection{Size}

Fruit size was measured using vernier caliper with an accuracy of $0.05 \mathrm{~mm}$ and then average values calculated.

\subsection{Titrable acidity (TA) and ascorbic acid}

Whole fruits were passed through an electric juicer (Nova Osaka Japan, NJ-506) and filtered. TA was determined by titration of $2 \mathrm{ml}$ juice diluted with $25 \mathrm{ml}$ distilled water with $0.1 \mathrm{~N}$ $\mathrm{NaOH}$ using $1 \%$ phenolphthalein as indicator and expressed as percentage citric acid (Mitcham, Cantwell, \& Kader, 2003).
Ascorbic acid was determined by iodine titration (AOAC, 2000).

\subsection{Weight loss}

Fruits for each treatment were marked before storage and weighed using a digital electronic balance with an accuracy of $0.0001 \mathrm{~g}$. Calculation was done from the weight of each papaya measured initially and at 4-day intervals during storage (Equation 1).

$$
\% \text { Weight loss }=\frac{\text { Initial weight }- \text { Final weight }}{\text { Initial weight }} \times 100
$$

\subsection{Percentage Disease Index (PDI)}

Disease index was measured by assessing the number of fruits infected during storage period. It was performed to check the ability of the coating material to prevent fruit disease. It was calculated as \% disease index (Equation 2):

$\mathrm{PDI}=$ no. of infection categories $/$ no. of infected fruit falling to this category $x$ 100/maximum no. of infection categories.

Infection categories were: $0=$ no lesion; $1=5$ to $\leq 15 \% ; 2=\geq 15 \%$ to $\leq 25 \% ; 3=\geq 25 \%$ to $\leq 50 \% ; 4=\geq 50 \%$ to $\leq 75 \% ; 5=\geq 75 \%$. For estimation of fruit area diseased, the whole fruit area was considered as $100 \%$ and thus the infected area was determined by visual estimation for percent of disease Index (Hossain, Hossain, Bakr, Rahman, \& Uddin, 2010).

\subsection{Peel color, flavor and firmness}

Fruits were evaluated for their firmness, color, flavor and overall acceptability. This was carried out by a panel of 10 members to make judgment more accurate. Peel color was measured visually based on skin color change initially and during storage intervals. Color was assessed visually by matching sample fruits with 'Maturity stages of Maradol papaya' (Basulto et al., 2009) with some modification. For each treatment 25 fruits 
were used. Five fruits were assessed at each interval. For control treatment initially (0 day) all the fruits were bright green, so this was expressed as $100 \%$ bright green. At 4-day intervals fruits were assessed for ratios of green to yellow coloration, and color percentages were calculated.

Subjective (non-destructive) fruit firmness was recorded by finger pressure using the scale: 6 $=$ very firm; $5=$ firm; $4=$ moderately firm; $3=$ slightly soft; $2=$ soft; $1=$ very soft. In order to obtain more accurate data, a panel of 10 members was employed instead of one person as tester (Shahnawaz \& Sheikh, 2011). The overall flavor of all papaya was perceived by the nose by the panel members to detect whether the flavor was satisfactory enough for consumer acceptance.

\subsection{Statistical analysis}

Physico-chemical results were subjected to analysis of variance (one way ANOVA) using SPSS package (version 17). Treatment means were separated by comparing the means at $\mathrm{p} \leq 0.05$ using Duncan's Multiple Range Test (Duncan, 1951).

\section{Results and discussion}

\section{$3.1 \mathrm{pH}$ value}

The $\mathrm{pH}$ increased significantly $(\mathrm{P} \leq 0.05)$ with increased storage time both in uncoated and coated fruits (Table 1 ). The mean $\mathrm{pH}$ value of the control fruits was 8.76 whereas minimal change was noticed in $\mathrm{pH}$ values of AG (7.80) and PLEAG (7.60) coated fruits after 8 days storage. After 12 days storage the $\mathrm{pH}$ values of the coated fruits increased further with the lowest value (7.98) in PLEAG coated fruits. Coatings slowed the changes in $\mathrm{pH}$, effectively delaying fruit senescence. This was due to the semi-permeable coating on the fruit surface which modified the internal atmosphere i.e., the endogenous $\mathrm{CO}_{2}$ and $\mathrm{O}_{2}$ concentration of the fruit. This statement is supported by the study of Bai, Huang, and Jiang (1988). The organic acids present in papaya are largely citric acid and malic acids. The increase in $\mathrm{pH}$ during storage was due to the metabolic processes of the fruit that resulted in a decrease of the organic acids Coseteng and Lee (1987).

\subsection{Total soluble solid content}

The coating with two bio-preservatives (PLEAG) led to a smaller increase in TSS content than the control fruits (Table 1). Data showed that control fruits had significantly $(\mathrm{p} \leq 0.05)$ higher levels of TSS(10.67) after 8 days storage, whereas the lowest value (7.40) of TSS was found in the PLEAG coated fruits after 12 days storage. The increase in TSS of control fruits was mainly due to the progressive boost in free sugars of fruit during storage periods, as reported by Cheour et al. (1990). Coated fruits retarded TSS development because aloe gel decreases the respiration and eventually catabolism of sugars. A similar result was found in Aloe gel-coated nectarines (Ahmed et al., 2009).

\subsection{Titrable acidity (TA)}

TA is an important parameter that determines the quality of papaya fruit and can affect consumer acceptance. Very high or very low acidity content is not recommended for good fruits. Control fruits showed rapid decrease in TA whereas coated fruits retained their TA content (Table $2)$. Control fruits had the lowest value (0.052) of TA $(\mathrm{p} \leq 0.05)$ after 8 days storage while highest TA retention was found in PLEAG coated fruits (0.142) after 12 days storage. This retention of TA content by coated fruits was due to the protective effect of aloe gel coating as a barrier to $\mathrm{O}_{2}$ from the surrounding atmosphere (Valverde et al., 2005). This result was also found in semperfresh coated pepper (Ozden \& Bayindirli, 2002), starch in strawberries (Mali \& Grossmann, 2003), in mango pulp (Baldwin et al., 1999), chitosan in lychee (Jiang, Li, \& Jiang, 2005), Aloe vera gel in table grape (Castillo et al., 2010) and aloe gel in 'star king' cherries (Martinez-Romero et al., 2006).

\subsection{Weight loss percentage (WLP)}

Papaya contains about $90 \%$ water by weight (Jayathunge et al., 2011). Weight loss mainly occurs due to water loss by transpiration and loss of carbon reserves due to respiration (Zagory $\&$ Kader, 1988). The rate at which water is 
$130 \mid$ Brishti et al.

Table 1: Effect of coatings on pH and total soluble solids (TSS) of papaya

\begin{tabular}{cccc|ccc}
\hline & & \multicolumn{3}{c}{ TSS } \\
\hline Period & Control & AG & PLEAG & Control & AG & PLEAG \\
0 d & $7.7 \pm 0.27^{a}$ & $7.56 \pm 0.37^{a}$ & $7.40 \pm 0.41^{a}$ & $6.80 \pm 0.44^{a}$ & $6.6 \pm 0.54^{a}$ & $6.80 \pm 0.44^{a}$ \\
$\mathbf{4} \mathbf{d}$ & $8.24 \pm 0.25^{a}$ & $7.58 \pm 0.42^{a}$ & $7.44 \pm 0.55^{a}$ & $9.2 \pm 0.83^{b}$ & $6.80 \pm 0.44^{a}$ & $5.80 \pm 1.7^{a}$ \\
$\mathbf{8} \mathbf{d}$ & $8.76 \pm 0.23^{b}$ & $7.80 \pm 0.46^{a}$ & $7.60 \pm 0.49^{a}$ & $10.67 \pm 1.15^{b}$ & $7.00 \pm 1.15^{a}$ & $6.20 \pm 0.83^{a}$ \\
$\mathbf{1 2} \mathbf{d}$ & $* *$ & $8.36 \pm 0.05^{a}$ & $7.98 \pm 0.39^{a}$ & $* *$ & $8.7 \pm 1.15^{a}$ & $7.40 \pm 0.54^{a}$ \\
\hline
\end{tabular}

** Indicates complete damage of fruits

\# Significance tests were carried out during storage period. Mean \pm S.D. in a row followed by different letters are significantly $(\mathrm{p} \leq 0.05)$ different (DMRT).

(AG: Aloe gel-coated fruits; PLEAG: Papaya leaf extract incorporated Aloe gel-coated fruits).

Table 2: Effect of coatings on acidity content and weight loss of papaya

\begin{tabular}{cccc|ccc}
\hline \multicolumn{4}{c|}{ Titrable acidity } & \multicolumn{3}{c}{ Weight loss } \\
\hline Period & Control & AG & PLEAG & Control & AG & PLEAG \\
0 d & $0.19 \pm 0.01^{a}$ & $0.194 \pm 0.00^{a}$ & $0.194 \pm 0.00^{a}$ & $0.00^{a}$ & $0.00^{a}$ & $0.00^{a}$ \\
$\mathbf{4} \mathbf{d}$ & $0.150 \pm 0.01^{a}$ & $0.174 \pm 0.02^{a b}$ & $0.188 \pm 0.02^{b}$ & $17.22 \pm 1.45^{b}$ & $15.18 \pm 1.77^{b}$ & $12.00 \pm 2.09^{a}$ \\
$\mathbf{8} \mathbf{d}$ & $0.052 \pm 0.00^{a}$ & $0.130 \pm 0.05^{b}$ & $0.158 \pm 0.03^{b}$ & $22.5 \pm 0.70^{a}$ & $7.93 \pm 2.76^{b}$ & $6.5 \pm 0.79^{b}$ \\
$\mathbf{1 2} \mathbf{d}$ & $* *$ & $0.116 \pm 0.00^{a}$ & $0.142 \pm 0.02^{a}$ & $* *$ & $10.70 \pm 0.50^{a}$ & $8.71 \pm 0.53^{b}$ \\
\hline ** Indicates complete damage of fruits
\end{tabular}

\# Significance tests were carried out during storage period. Mean \pm S.D. in a row followed by different letters are significantly $(\mathrm{p} \leq 0.05)$ different (DMRT).

(AG: Aloe gel coated fruits; PLEAG: Papaya leaf extract incorporated Aloe gel coated fruits)

lost depends on the water pressure gradient between the fruit tissue and the surrounding atmosphere. Generally, the WLP increased gradually $(\mathrm{p} \leq 0.05)$ during storage (Table 2$)$. Control fruits had significantly $(\mathrm{p} \leq 0.05)$ higher WLP $(22.5 \%)$ whereas lower WLP $(6.5 \%)$ was found in PLEAG coated fruits after 8 days storage.

Table 2 shows that for coated fruits WLP decreased on the $8^{\text {th }}$ day compared to the $4^{\text {th }}$ day. A similar result was also found in apricot fruit treated with $0.75 \%$ chitosan (Ghasemnezhad, Shiri, \& M. 2010). This was due to the hygroscopic properties of aloe gel that allow the formation of water barrier between the fruit and the surrounding environment, thus preventing its external transferences (Morillon, Debeaufort, Blond, Capelle, \& Voilley, 2002). Similarly aloe gel also suppressed weight loss for 'Arctic Snow' nectarines treated with $2.50 \%$ aloe gel stored at $20{ }^{\circ} \mathrm{C}$ (Ahmed et al., 2009), 'star king' cherries treated with $33 \%$ aloe gel at $1{ }^{\circ} \mathrm{C}$ (MartinezRomero et al., 2006) and 'Autumn Royal' table grapes treated with $33 \%$ aloe gel stored at $2{ }^{\circ} \mathrm{C}$ (Castillo et al., 2010).

\subsection{Percentage Disease index (PDI)}

PDI was used to observe the effectiveness of coated material on fruit in retarding fruit disease. No disease signs were observed until 1 week after the beginning of storage period. This was due to the anti-microbial potentiality of coated materials. At 12 days storage $100 \%$ disease incidence was observed in controls, whereas for AG and PLEAG coated fruits disease incidence was only $27 \%$ and $13 \%$, respectively (Table 3). Aloe gel and papaya leaf juice contain bioactive agents which mainly serve to prevent papaya fruit disease (Bautista-Baños, Hernández-López, Barrera-Necha, \& BermúdezTorres, 2000; Habeeb et al., 2007). Aloe gel-based coating also retard microorganism proliferation 
Effect of Biopreservatives on papaya $\mid 131$

Table 3: Effect of coatings on ascorbic acid (AA) content and percentage disease index (PDI) of papaya

\begin{tabular}{|c|c|c|c|c|c|c|}
\hline \multicolumn{4}{|c|}{ PDI } & \multicolumn{3}{|c|}{ AA $(\mathrm{mg} / 100 \mathrm{~g})$} \\
\hline Period & Control & AG & PLEAG & Control & $\mathbf{A G}$ & PLEAG \\
\hline $0 \mathrm{~d}$ & - & - & - & 59.00 & 64.70 & 93.80 \\
\hline $4 \mathrm{~d}$ & - & - & - & 62.26 & 87.49 & 103.40 \\
\hline $8 d$ & $60 \%(>75 \%)$ & $10 \%(<15-<25 \%)$ & $5 \%(<15 \%)$ & 61.10 & 86.55 & 107.07 \\
\hline $12 \mathrm{~d}$ & $100 \%(>75 \%)$ & $27 \%(>15-<25 \%)$ & $13 \%(<15 \%)$ & ** & 96.87 & 120.20 \\
\hline
\end{tabular}

** Indicates complete damage of fruits

- Indicates no disease

Table 4: Effect of coatings on size value and firmness of Papaya

\begin{tabular}{cccc|ccc}
\hline & \multicolumn{2}{c|}{ Size $(\mathrm{mm})$} & \multicolumn{3}{c}{ Firmness } \\
\hline Period & Control & AG & PLEAG & Control & AG & PLEAG \\
0 d & $86.97 \pm 1.19^{a b}$ & $87.61 \pm 2.63^{b}$ & $84.60 \pm 0.83^{a}$ & $6 \pm 0.00^{a}$ & $6 \pm 0.00^{a}$ & $6 \pm 0.00^{a}$ \\
4 d & $82.31 \pm 1.97^{a}$ & $86.66 \pm 1.97^{b}$ & $87.31 \pm 2.17^{b}$ & $3.2 \pm 0.44^{a}$ & $4.2 \pm 0.44^{b}$ & $5.6 \pm 0.54^{c}$ \\
$\mathbf{8} \mathbf{d}$ & $69.99 \pm 1.36^{a}$ & $86.73 \pm 1.72^{b}$ & $86.12 \pm 0.76^{b}$ & $1.5 \pm 0.70^{a}$ & $3.25 \pm 0.50^{b}$ & $3.60 \pm 0.54^{b}$ \\
$\mathbf{1 2} \mathbf{d}$ & $*^{* *}$ & $83.97 \pm 1.47^{a}$ & $84.15 \pm 0.64^{a}$ & $* *$ & $3 \pm 0.00^{a}$ & $3.2 \pm 0.54^{a}$ \\
\hline
\end{tabular}

** Indicates complete damage of fruits

\# Significance tests were carried out during storage period. Mean \pm S.D. in a row followed by different letters are significantly $(\mathrm{p} \leq 0.05)$ different (DMRT).

(AG: Aloe gel coated fruits; PLEAG: Papaya leaf extract incorporated Aloe gel coated fruits)

Table 5: Ripening condition of papaya

\begin{tabular}{|c|c|c|c|c|c|c|c|c|c|c|c|c|c|c|c|}
\hline \multirow{5}{*}{$\begin{array}{c}\text { Period } \\
0 \mathrm{~d} \\
4 \mathrm{~d}\end{array}$} & \multicolumn{15}{|c|}{$\frac{\text { Ripening of papaya }}{\text { Peel Color }(\%)}$} \\
\hline & \multicolumn{5}{|c|}{ Control } & \multicolumn{5}{|c|}{$\mathbf{A G}$} & \multicolumn{5}{|c|}{ PLEAG } \\
\hline & 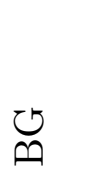 & 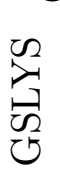 & $\sum_{0}^{\infty}$ & $\begin{array}{l}\varangle \\
\mho \\
0 \\
0\end{array}$ & 焉 & $\mho_{\oplus}$ & 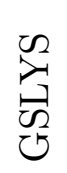 & $\sum_{\substack{n \\
i}}^{\infty}$ & $\begin{array}{l}\mathbb{J} \\
\vdots \\
0 \\
0\end{array}$ & 旁 & U & 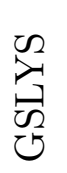 & $\sum_{\substack{\infty \\
0}}^{\infty}$ & 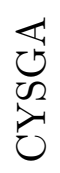 & 窟 \\
\hline & 100 & & & & & 100 & & & & & 100 & & & & \\
\hline & & 40 & 60 & & & 100 & & & & & 100 & & & & \\
\hline $8 \mathrm{~d}$ & & & & 60 & 40 & 80 & & 20 & & & 80 & 20 & & & \\
\hline $12 \mathrm{~d}$ & $* *$ & ** & $* *$ & $* *$ & $* *$ & 60 & & 40 & & & 40 & 20 & 40 & & \\
\hline
\end{tabular}

\# BG=Bright Green, GSLYS=Green Skin with Light Yellow Stripe, GSWYS= Green Skin with Well-defined Yellow Stripe, CYSGA = Clearly Yellow Colored Skin with some Green Areas, CHAYS=Characteristic Yellow colored Skin. ** Indicates complete damage of fruits

(AG: Aloe gel-coated fruits; PLEAG: Papaya leaf extract incorporated Aloe gel-coated fruits) 
Table 6: Overall appearance of papaya

\begin{tabular}{lccccc}
\hline Treatments & \multicolumn{4}{c}{ Appearance } \\
& $\begin{array}{lcccc}\text { Storage } \\
\text { Periods }\end{array}$ & Color & Flavor & Firmness & Remarks \\
& 0 days & BG(5) & Satisfactory & Very Firm & Good \\
Control & 4 days & GSLYS+GSWYS & Satisfactory & Slightly soft & Good \\
& 8 days & CYSGA+CHAYS & Unsatisfactory & Very soft & Inferior \\
& 12 days & $* *$ & $* *$ & $* *$ & ** \\
\hline AG & 0 days & BG & Satisfactory & Very firm & Good \\
& 4 days & BG & Satisfactory & Moderately firm & Good \\
& 8 days & BG+GSWYS & Satisfactory & Slightly soft & Good \\
& 12 days & BG+GSWYS & Satisfactory & Slightly soft & Good \\
\hline PLEAG & 0 days & BG & Satisfactory & Very firm & Good \\
& 4 days & BG & Satisfactory & Very firm & Good \\
& 8 days & BG+GSLYS & Satisfactory & Moderately firm & Good \\
& 12 days & BG+GSLYS+GSWYS & Satisfactory & Slightly soft & Good \\
\hline
\end{tabular}

** Indicates complete damage of fruits.

\# BG=Bright Green, GSLYS=Green Skin with Light Yellow Stripe, GSWYS= Green Skin with Well-defined Yellow Stripe, CYSGA = Clearly Yellow Colored Skin with some Green Areas, CHAYS=Characteristic Yellow colored Skin.

in sweet cherries (Martinez-Romero et al., 2006) and table grapes (Valverde et al., 2005).

\subsection{Ascorbic acid (AA) content}

Table 3 shows that control fruits initially contained $59 \mathrm{mg}$ AA, while AG and PLEAG coated fruits contained 64.7 and $93.8 \mathrm{mg}$ AA, respectively. This variance in ascorbic acid content of fruits was due to differences in light intensity obtained during growth on the plant. The coated fruits were exposed to more light intensity during growth for which they contained higher AA than the control fruits. This statement is supported by Harris (1975).

Over time the ascorbic acid content of coated and uncoated fruits increased with the highest value $(120.2 \mathrm{mg})$ found in PLEAG-coated fruits at 12 days storage (Table 3 ). This was due to low oxygen permeability of coating which delayed the deteriorative oxidation reaction of AA content (Ayranci \& Tunc, 2003). This was also found by Howard and Hernandez-Brenes (1998). Sumnu and Bayindirli (1994) reported that coating reduces respiration of the fruits and retains the ascorbic acid in the fruits.

\subsection{Size value}

The mean size value of AG (86.73 mm) and PLEAG $(86.12 \mathrm{~mm})$ coated fruits was significantly $(\mathrm{p} \leq 0.05)$ different from control fruits (69.99 $\mathrm{mm})$ after 8 days storage (Table 4$)$. Water loss causes shrinkage and loss of weight. Size was measured to determine the effect of coated material on fruit shrinkage. There was maximum reduction $(16.98 \mathrm{~mm})$ in size of control fruits and minimum reduction in the PLEAG coated fruits (0.45 mm) after 8 days storage. This was due to the greater water loss in control fruits and less loss in coated fruits.

\subsection{Firmness}

The initial firmness values were similar for both uncoated (control) and coated fruits $(\mathrm{p} \leq 0.05)$. After 8 days storage, the control fruits began to show a gradual loss of firmness compared to the coated fruits. At 12 days of storage, control fruits decayed and the coated fruits were slightly soft but did not differ significantly $(\mathrm{p} \leq 0.05)$. This indicated that the ripening of coated fruits was delayed by delaying softening (Table 4 ). Loss of texture is one of the main factors limiting quality 
and post-harvest shelf life of fruits and vegetables. Fruits softening occurs considerably during ripening which is mainly as a result of degradation of the middle lamella of the cell wall of cortical parenchyma cells (Perkins-Veazie, 2010). Changes in cell wall structure and in their composition are mainly due to the combined action of enzymes including hydrolases, particularly polygalacturonase $(\mathrm{PG})$, pectinestarage $(\mathrm{PE}), \beta$ Galactosidase $(\beta-\mathrm{Gal})$, pectate lyase $(\mathrm{PL})$ and cellulose (Cel) (Brummell \& Harpster, 2001). Treatment with AG and PLEAG significantly reduced the loss of firmness and this can be associated with less weight loss. A similar result was found in coated strawberries (Del-Valle, Hernandez-Munoz, Guarda, \& Galotto, 2005) and cherries (Alonso \& Alique, 2004). In addition, Aloe gel has a role in the reduction of activity of $\mathrm{PG}, \mathrm{PE}$ and $\beta$-Gal enzymes responsible for fruit softening and also maintains the pectin (Martinez-Romero et al., 2006).

\subsection{Peel color change}

Color is one of the most important visual attributes of papaya. The bright green color of control and coated fruits changed to yellow color after storage period. Complete yellowness was found after 8 days storage of control fruits, whereas green skin with well defined yellow stripe was found at 12 days storage period of coated fruits (Table 5).

Visual assessment is the first impression and a key feature in the choice of the fruit. Surface color of papaya is one of the most important criteria in determining ripening of papaya. Color retention of coated fruits was due to the delay in ripening of coated fruits. The modified atmosphere created by the edible coating material retarded the ethylene production rate, therefore, delaying ripening, chlorophyll degradation and carotenoid synthesis thus ultimately delaying color change of fruits (Carrillo-Lopez, RamirezBustamante, Valdez-Torres, Rojas-Villegas, \& Yahia, 2000; Hoa, Ducamp, Lebrun, \& Baldwin, 2002).

\subsection{Overall appearance of papaya}

The overall appearance of control papayas (a combination of "green skin with light yellow stripe" and "green skin with well defined yellow stripe") was acceptable up to 4 days but it became inferior from the $6^{\text {th }}$ day onward (Table 6 ). The flavor of fruits was found to be satisfactory and firmness was slightly soft. However, after the $6^{\text {th }}$ day the papayas started to deteriorate as they ripened fully and peel color changed to a combination of "clearly yellow colored skin with some light green areas" and "characteristic yellow skin". At $8^{\text {th }}$ day their firmness became very soft and flavor was completely unsatisfactory. In the case of AG-coated fruits, the color was "bright green" until the $4^{\text {th }}$ day of storage, but from the $6^{\text {th }}$ day they started to show a color combination of "bright green" and "green skin with well defined yellow stripe". At $8^{\text {th }}$ day their firmness became slightly soft and even at $12^{\text {th }}$ day they were also slightly soft. During storage intervals $(0,4,8$ and 12 days) their flavor was found to be satisfactory. In the case of the PLEAG-coated fruits, the color was "bright green" until $4^{\text {th }}$ day and at $8^{\text {th }}$ day color became a combination of "bright green" and "green skin with light yellow stripe". At $12^{\text {th }}$ day it became a combination of "bright green", "green skin with light yellow stripe" and "green skin with well defined yellow stripe". Their firmness was moderate at $8^{t h}$ day and at $12^{t h}$ day they were slightly soft. Like AG-coated papayas, the flavor of PLEAG-coated fruits was satisfactory over the whole storage period. The AG- and PLEAG-coated papayas started to decay at $16^{\text {th }}$ day with unpleasant flavor.

\section{Conclusions}

Fruits face tremendous loss due to old-fashioned preservation practice and ignorance about preservation strategies. Chemical preservatives which are now used widely can have dangerous effects on health such as various types of cancers, kidney and liver damage, etc. This work revealed that the AG- and PLEAG-coated fruits acquired an extended shelf life and the coatings preserved the valuable attributes of the fruit. 
This work recommends Aloe gel as a successful biopreservative and a useful alternative to synthetic preservative. Having no adverse effect on fruits, environment and consumers health, Aloe vera gel could easily and safely be applied to papaya fruits. The application of edible coatings could easily be integrated in the current handling system. Furthermore, as demonstrated, incorporation of papaya leaf juice to the Aloe gel as an anti-fungal natural additive makes Aloe gel more effective and convenient in controlling fungus growth on papaya.

\section{References}

Ahmed, M. J., Singh, Z., \& Khan, A. S. (2009). Postharvest Aloe vera gel-coating modulates fruit ripening and quality of 'Arctic Snow' nectarine kept in ambient and cold storage. International Journal of Food Science and Technology, 44(5), 1024-1033. doi:10.1111/j.1365-2621.2008.01873.x

Alonso, J, \& Alique, R. (2004). Influence of edible coating on shelf life and quality of "Picota" sweet cherries. European Food Research and Technology, 218(6), 535-539. doi:10.1007/s00217-004-0908-3

AOAC. (2000). Official methods of analysis. 17th Ed., Association of Official Analytical Chemistry, Arlington, Virginia, USA.

Archbold, D., Koslanund, R, \& Pomper, K. (2003). Ripening and postharvest storage of pawpaw. Horttechnology, 13(3), 439441.

Ayranci, E, \& Tunc, S. (2003). A method for the measurement of the oxygen permeability and the development of edible films to reduce the rate of oxidative reactions in fresh foods. Food Chemistry, 80(3), 423431. doi:10.1016/S0308-8146(02)00485-5

Bai, R.-K., Huang, M.-Y., \& Jiang, Y.-Y. (1988). Selective permeabilities of chitosan-acetic acid complex membrane and chitosanpolymer complex membranes for oxygen and carbon dioxide. Polymer Bulletin, 20, 83-88. doi:10.1007/BF00262253

Baldwin, E. (1994). Edible coatings for fresh fruits and vegetables: past, present, and future, edible coatings and films to im- prove food quality. in (eds) krochta, j., baldwin, e. \& nisperos-carriedo, m.. edible coatings and films to improve food quality, (25p). Lancaster: Technomic Publishing Company. Retrieved from http://books . google.pt/books?id=zS8YmyouBjwC

Baldwin, E., Burns, J., Kazokas, W, Brecht, J., Hagenmaier, R., Bender, R., \& Pesis, E. (1999). Effect of two edible coatings with different permeability characteristics on mango (Mangifera indica L.) ripening during storage. Postharvest Biology and Technology, 17(3), 215-226. doi:10.1016/ S0925-5214(99)00053-8

Basulto, F., Duch, E., Gil, F., Plaza, R., Saavedra, A., \& Santamaría, J. (2009). Postharvest Ripening and Maturity Indices for Maradol Papaya. Interciencia, 34(8), 583588.

Bautista-Baños, S., Barrera-Necha, L., BravoLuna, I., \& Bermúdez-Torres, L. (2002). Antifungal activity of leaf and stem extracts from various plant species on the incidence of Colletotrichum gloesporoides of papaya and mango fruit after storage. Revista Mexicana Fitopatologia, 20, 8-12.

Bautista-Baños, S., Hernández-López, M., Barrera-Necha, L., \& Bermúdez-Torres, L. (2000). Antifungal screening of plants of the state of morelos, mexico against four fungal postharvest pathogens of fruits and vegetables. Revista Mexicana Fitopatologia, 18, 36-41.

Brummell, D., \& Harpster, M. (2001). Cell wall metabolism in fruit softening and quality and its manipulation in transgenic plants. Plant Molecular Biology, 47(1-2), 311-340. doi:10.1023/A:1010656104304

Carrillo-Lopez, A, Ramirez-Bustamante, F, Valdez-Torres, J., Rojas-Villegas, R, \& Yahia, E. (2000). Ripening and quality changes in mango fruit as affected by coating with an edible film. Journal of Food Quality, 23(5), 479-486. doi:10.1111/j . 1745-4557.2000.tb00573.x

Castillo, S., Navarro, D., Zapata, P. J., Guillen, F., Valero, D., Serrano, M., \& MartinezRomero, D. (2010). Antifungal efficacy of Aloe vera in vitro and its use as a preharvest treatment to maintain postharvest ta- 
ble grape quality. Postharvest Biology and Technology, 57(3), 183-188. doi:10.1016/j. postharvbio.2010.04.006

Cheour, F., Willemot, C., Arul, Y., Desjardins, J., Makhlouf, P., \& Gosselin, A. (1990). Effects of foliar application of $\mathrm{Cacl}_{2}$ on postharvest strawberry ripening. Journal of the American Society for Horticultural Science, 115(5), 789-792.

Coseteng, M., \& Lee, C. (1987). Changes in Apple Polyphenoloxidase and Polyphenol Concentrations in Relation to Degree of Browning. Journal Of Food Science, 52(4), 985-989. doi:10.1111/j.1365-2621.1987. tb14257.x

Del-Valle, V, Hernandez-Munoz, P, Guarda, A, \& Galotto, M. (2005). Development of a cactus-mucilage edible coating (Opuntia ficus indica) and its application to extend strawberry (Fragaria ananassa) shelf-life. Food Chemistry, 91(4), 751-756. doi:10 . 1016/j.foochem.2004.07.002

Duncan, D. B. (1951). A significant test for differences between ranked treatments in an analysis of variance. Virginia Journal of Science, 2(9), 171-189.

El-Kadder, E. M. A., \& Hammad, H. (2012). In vitro propagation of dillenia indic. Australian Journal of Basic and Applied Sciences, 6(7), 452-457.

Gebhardt, S. E., \& Thomas, R. G. (2002). Nutritive value of foods. Washington US Dept. of Agric. Res. Service, Home and Garden Bulletin: 72. Retrieved from http://www. nal.usda.gov/fnic/foodcomp/Data/HG72/ hg72_2002.pdf

Ghasemnezhad, M., Shiri, M. A., \& M., S. (2010). Effect of chitosan coatings on some quality indices of apricot (prunus armeniaca 1.) during cold storage. Caspian Journal of Environmental Science, 8(1), 25-33.

Guilbert, S, Gontard, N, \& Gorris, L. (1996). Prolongation of the shelf-life of perishable food products using biodegradable films and coatings. Food Science and TechnologyLebensmittel-Wissenschaft \& Technologie, 29(1-2), 10-17. doi:10.1006/fstl.1996.0002

Habeeb, F., Shakir, E., Bradbury, F., Cameron, P., Taravati, M. R., Drummond, A. J., ... Ferro, V. A. (2007). Screening meth- ods used to determine the anti-microbial properties of Aloe vera inner gel. Methods, 42(4), 315-320. doi:10.1016/j.ymeth.2007. 03.004

Hoa, T., Ducamp, M., Lebrun, M, \& Baldwin, E. (2002). Effect of different coating treatments on the quality of mango fruit. Journal Of Food Quality, 25(6), 471-486. doi:10.1111/j.1745-4557.2002.tb01041.x

Hossain, M., Hossain, S., Bakr, M., Rahman, A., \& Uddin, S. (2010). Survey on major diseases of vegetable and fruit crops in chittagong region. Bangladesh Journal of Agricultural Research, 35(3), 423-429. doi:10. 3329/bjar.v35i3.6449

Howard, L., \& Hernandez-Brenes, C. (1998). Antioxidant content and market quality of jalapeno pepper rings as affected by minimal processing and modified atmosphere packaging. Journal of Food Quality, 21 (4), 317-327. doi:10.1111/j. 1745-4557. 1998. tb00525.x

Jayathunge, K., Prasad, H., Fernando, M., \& Palipane, K. (2011). Prolonging the postharvest life of papaya using modified atmosphere packaging. Journal of Agricultural Technology, 7(2), 507-518. 3/4/2011. Retrieved from http://www.ijat-aatsea.com/ pdf / April_v7_n2_11 / 28 \\%20IJAT2010_ 23FT.pdf

Jiang, Y., Li, J., \& Jiang, W. (2005). Effects of chitosan coating on shelf life of cold-stored litchi fruit at ambient temperature. $L W T$ Food Science and Technology, 38(7), 757761. doi:10.1016/j.lwt.2004.09.004

Mali, S, \& Grossmann, M. (2003). Effects of yam starch films on storability and quality of fresh strawberries (Fragaria ananassa). Journal of Agricultural and Food Chemistry, 51(24), 7005-7011. doi:10 . 1021 / jf034241c

Martinez-Romero, D, Alburquerque, N, Valverde, J., Guillen, F, Castillo, S, Valero, D, \& Serrano, M. (2006). Postharvest sweet cherry quality and safety maintenance by Aloe vera treatment: A new edible coating. Postharvest Biology and Technology, 39(1), 93-100. doi:10.1016/j.postharvbio.2005.09.006 
Maughan, R. G. (1984). Method to increase color fastness of stabilized aloe vera. US Patent 4,465,629. Retrieved from http:// www . google.com/patents/US4465629? printsec= description $\# \mathrm{v}=$ onepage $\backslash \& \mathrm{q} \backslash \& \mathrm{f}=$ false

Mitcham, B., Cantwell, M., \& Kader, A. (2003). Methods for determining quality of fresh commodities. Perishables Handling Newsletter, 85, 1-5.

Morillon, V, Debeaufort, F, Blond, G, Capelle, M, \& Voilley, A. (2002). Factors affecting the moisture permeability of lipid-based edible films: A review. Critical Reviews in Food Science and Nutrition, 42(1), 67-89. doi:10.1080/10408690290825466

Nidiry, E., Ganeshan, G., \& Lokesha, A. (2011). Antifungal activity of some extractives and constituents of aloe vera. Research Journal of Medicinal Plant, 5(2), 196-200. doi:10. 3923/rjmp.2011.196.200

Oloyede, O. (2005). Chemical profile of unripe pulp of carica papaya. Pakistan Journal of Nutrition, 4(6), 379-381. doi:10.3923/pjn. 2005.379.381

Ozden, C, \& Bayindirli, L. (2002). Effects of combinational use of controlled atmosphere, cold storage and edible coating applications on shelf life and quality attributes of green peppers. European Food Research And Technology, 214(4), 320-326. doi:10. 1007/s00217-001-0448-z

Perkins-Veazie, P. (2010). Growth and ripening of strawberry fruit, In Horticultural reviews (Vol. 17, pp. 267-297). John Wiley \& Sons, Inc. doi:10.1002/9780470650585.ch8

Serrano, M, Valverde, J., Guillen, F, Castillo, S, Martinez-Romero, D, \& Valero, D. (2006). Use of Aloe vera gel coating preserves the functional properties of table Grapes. Journal of Agricultural and Food Chemistry, 54(11), 3882-3886. doi:10.1021/jf060168p

Shahnawaz, M., \& Sheikh, S. A. (2011). Physicochemical characteristics of jamun fruit. Journal of Horticulture and Forestry, 3(10), 301-306.

Sumnu, G, \& Bayindirli, L. (1994). Effects of Semperfresh(Tm) and Johnfresh(Tm) Fruit Coatings on Poststorage Quality of Ankara Pears. Journal of Food Processing and Preservation, 18(3), 189-199. doi:10. 1111/j.1745-4549.1994.tb00843.x

Tripathi, P, \& Dubey, N. (2004). Exploitation of natural products as an alternative strategy to control postharvest fungal rotting of fruit and vegetables. Postharvest Biology and Technology, 32(3), 235-245. doi:10. 1016/j.postharvbio.2003.11.005

Valverde, J., Valero, D, Martinez-Romero, D, Guillen, F, Castillo, S, \& Serrano, M. (2005). Novel edible coating based on Aloe vera gel to maintain table grape quality and safety. Journal of Agricultural and Food Chemistry, 53(20), 7807-7813. doi:10. 1021/jf050962v

Zagory, D, \& Kader, A. (1988). Modified Atmosphere Packaging of Fresh Produce. Food Technology, 42(9), 70-77. 